\title{
Megaesophagus in sheep and goats
}

\author{
Megaesôfago em ovinos e caprinos
}

\author{
Eduardo Melo Nascimento ${ }^{\mathrm{I}}$ Édipo Moreira Campos ${ }^{\mathrm{I}}$ Lisanka Ângelo Maia $^{\mathrm{I}}$ \\ Rosane Maria Trindade Medeiros ${ }^{I}$ Maria Dalva Bezerra de Alcântara ${ }^{I I}$ \\ Sara Dantas Vilar $^{\mathrm{I}}$ Franklin Riet-Correa ${ }^{\mathrm{I}}$, III
}

\section{ABSTRACT}

\begin{abstract}
Megaesophagus is a rare disease in ruminants characterized by regurgitation of rumen contents. In this paper it was described cases of megaesophagus in two sheep and two goats on a farm in the state of Paraiba, Northeastern Brazil. All animals showed regurgitation of rumen contents and weight loss, with a clinical course of several months. At necropsy all animals presented megaesophagus. Histological examination showed segmental muscle necrosis in the esophagus and skeletal muscles. Serum samples from one sheep and one goat were negative for the presence of blue tongue antibodies by ELISA, and whole blood and muscle samples from one goat were negative for this virus by RT PCR. Epidemiological data and pathology suggested that the disease could have been caused by some toxic plant, but known plants causing segmental muscle necrosis were not observed in the areas where the disease occurred.
\end{abstract}

Key words: megaesophagus, regurgitation, muscle necrosis, ruminants.

RESUMO

Megaesôfago é uma enfermidade rara em ruminantes caracterizada por regurgitação do conteúdo ruminal. Neste trabalho, descrevem-se casos de megaesôfago em dois ovinos e dois caprinos no Estado da Paraíba. Todos os animais apresentaram regurgitação do conteúdo ruminal e emagrecimento, com evolução de vários meses. Nas necropsias dos animais, observou-se dilatação esofágica $e$, em exames histológicos, necrose muscular segmentar no esôfago e músculos esqueléticos. Não foram encontrados anticorpos para o vírus da língua azul nos soros de um ovino e um caprino pela técnica de ELISA. Sangue total e músculo de um caprino resultaram negativos para esse vírus por RT PCR. Sugere-se que a doença seja causada por alguma planta tóxica, mas não foram encontradas plantas conhecidas por causarem necrose segmentar muscular nos piquetes onde ocorreu a doença.

Palavras-chave: megaesôfago, regurgitação, necrose muscular, ruminantes.

\section{INTRODUCTION}

In ruminants, the esophagus is responsible for the transport of liquids and solids from mouth to stomach, for eructation and for regurgitation of the bolus for rumination (SPILLMANN, 2007). Unlike other species, in ruminants, the muscle layer of the esophagus is composed only by striated muscles (McGAVIN, 2013).

Megaesophagus is an esophageal dysfunction resulting from atony of the esophageal musculature characterized by flaccidity and luminal dilation, as a consequence of segmental or diffused motor dysfunction of the esophageal body (TORRES, 1997). Findings usually observed in the clinical examination are regurgitation of food or water, salivation, retaining of food in the esophagus, progressive weight loss, cough and nasal discharge (LONGSHORE, 2008). In ruminants,

'Hospital Veterinário, Universidade Federal de Campina Grande (UFCG), Av. Universitária, s/n, 58.708-110, Patos, PB, Brasil. E-mail: franklin.riet@pq.cnpq.br. "Corresponding author.

"Empresa Paraibana de Pesquisa Agropecuária (EMEPA), Soledade, PB, Brasil.

"IIInstituto Nacional de Investigación Agropecuaria (INIA), Estación Experimental La Estanzuela, Colonia del Sacramento, Colonia, Uruguay. 
megaesophagus can cause bloat by obstructing the eructation (RADOSTITS et al., 2007). Animals with megaesophagus eventually succumb to the effects of chronic malnutrition, and have the risk of aspiration pneumonia (SPILLMANN, 2007).

The disease has been reported in several domestic species, being quite common in dogs (MILLER et al., 1983). It may be congenital and hereditary, associated to abnormalities in the development of esophageal innervation, persistence of the fourth right aortic arch or vagus nerve disorders (SHELTON et al., 2003). Congenital megaesophagus, possibly hereditary, was also reported in Murrah buffalo (DAME et al., 2013). Cases of megaesophagus can also be caused by traumas or by compression or obstruction of the esophagus by food, foreign bodies, neoplasia and hiatal hernia (VALENTINE \& McGAVIN, 2013). The disease is rare in sheep and goats. In these species it was described in an one year old sheep with signs of food regurgitation (BRAUN et al., 1990) and in a 2 years old goat with regurgitation and increased neck volume (distal neck) (MOZAFFARI \& VASOUGH, 2007).

This paper reports the clinical signs and gross and microscopic changes of a disease observed in two sheep and two goats in the state of Paraíba, characterized by regurgitation and megaesophagus.

\section{MATERIALS AND METHODS}

The affected animals belonged to Empresa Estadual de Pesquisa Agropecuária da Paraíba (EMEPA - Farming Research Company of the State of Paraíba) and were raised in the Experimental Station of Pendência, located in the city of Soledade, state of Paraíba. The epidemiologic data were gathered during visits to the farm for observation of the animals and inspection of the pastures. Two sheep and two goats showing clinical signs of regurgitation were sent to the Veterinary Hospital of UFCG (Universidade Federal de Campina Grande) in the city of Patos.

A blood sample from one of the sheep (Sheep 1) was taken and sent to Instituto Biológico de São Paulo (Biological Institute of the State of São Paulo) to detect blue tongue virus antibodies by ELISA. Total blood and muscle samples from Goat 2 were sent to the Virology Laboratory of Universidade Federal de Santa Maria (Santa Maria Federal University) for detection of blue tongue virus by RT PCR using starter oligonucleotides for segment 7 of this virus. Serum samples from this goat were sent to the Instituto Biológico de São Paulo for detection of blue tongue antibodies by ELISA.

The four affected animals were euthanized in accordance with the Resolution number 1000 of the Brazilian Veterinary Medicine Board, from May $11^{\text {th }}$, 2012. Samples from skeletal muscles, esophagus, tongue, thyroids, peripheral lymph nodes, central nervous system and organs of the abdominal and thoracic cavities were fixed in $10 \%$ neutral formalin, embedded in paraffin, sectioned at $5 \mu \mathrm{m}$ and stained by hematoxylin and eosin for histological study

\section{RESULTS}

In the farm were raised 270 animals, including goats and sheep from different breeds and ages. The disease occurred between October 2010 and April 2014, in two sheep and two goats in a flock composed by 50 bucks and 40 rams, raised in semiextensive system. Those animals were grazing every morning in a 50 hectare paddock with native caatinga pasture and led in the evening to pens where they were fed with Brachiaria grass, corn and sorghum silage, Buffel grass hay, and corn and soy concentrate. Volumous feed was offered ad libitum and the concentrate at $1 \%$ of live weight.

In October 2010 two Dopper rams (Sheep 1 and 2) showed weight loss and regurgitation, with permanent presence of rumen content in the stall floor. After 20 days from the first signs the animals were taken to the Veterinary Hospital of Universidade Federal de Campina Grande.

Sheep 1 was a 3 -years-old ram and in the clinical examination we found moderate dehydration, diarrheic feces and mouth stained by regurgitated rumen content (Figure 1A). The animal stayed in the Hospital for two months and due to the progressive weight loss it was euthanized.

Sheep 2 was a 5-years-old ram and had a less intense regurgitation than sheep 1 . For two months the clinical signs remained unchanged, leading to the decision to send it back to the Experimental Station of Pendência, where it remained with the signs until September 2011, when it was taken again to the Hospital. In a new physical exam it was noticed a difficulty to hold food and frequent regurgitation of rumen content often happening 40 to 60 minutes after ingestion of food and during the night. Due to the worsening of the clinical signs the animal was euthanized eight days after its admission in the hospital. 


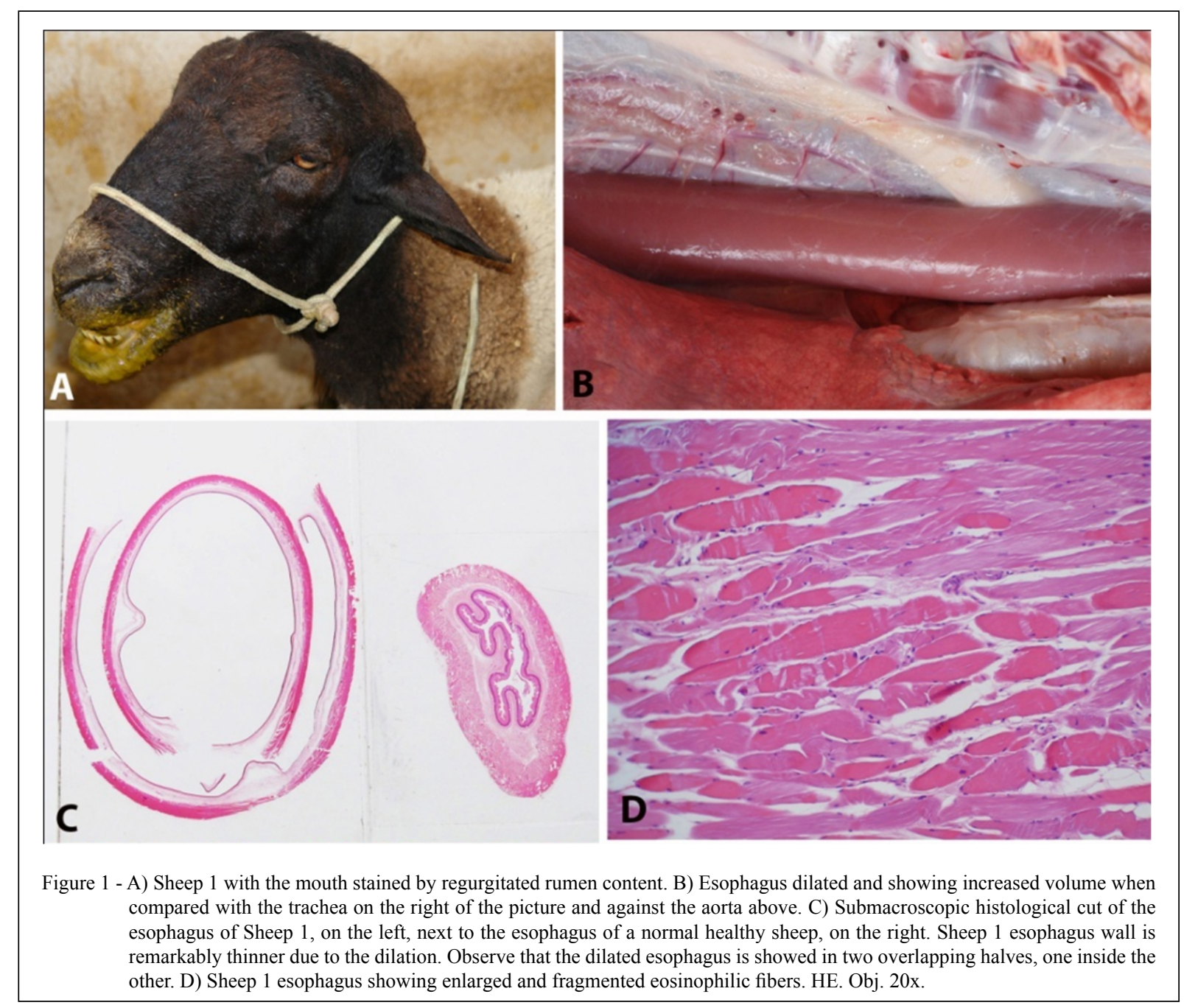

Goat 1 was a 2-years and 9-months-old Savanna breed buck. It was attended in the Veterinary Hospital in April 2012 with intense regurgitation and progressive weight loss. At the physical examination the animal was apathetic, thin and had difficulty to hold and swallow food. Considering the irreversibility and the seriousness of the signs, it was euthanized and sent to necropsy after one day in the hospital.

Goat 2 was a 5-years-old Alpine Brown breed buck. It was attended in the Veterinary Hospital in June 2014 with a six month regurgitation history, cough and progressive weight loss. At the clinical examination the animal was apathetic, thin and had regurgitation episodes, mainly during feeding. After 20 days in the hospital and a worsening in the clinical picture, it was euthanized. Serum samples from sheep 1 and goat 2 were negative for blue tongue virus antibodies and whole blood and muscles of goat 2 were negative to blue tongue virus by RT PCR.

During the necropsies of the four animals, esophageal dilation was observed and it was more evident in sheep 1 (Figure 1B and 1C) and in goat 2. In the lung of sheep 1 the ventral lobes showed reddish, consolidated areas with yellowed multifocal nodules. Histologically the muscular layer of the esophagus showed polyphasic segmental necrosis characterized by enlarged and fragmented eosinophilic muscle fibers with loss of cross striations, with the presence of scarce macrophages randomly distributed in the lesion (Figure 1D). Some muscle fibers showed clear and granulated cytoplasm, with few areas of mineralization. Several skeletal muscles showed polyphasic segmental necrosis (Figure 2) characterized by enlarged eosinophilic fibers with 


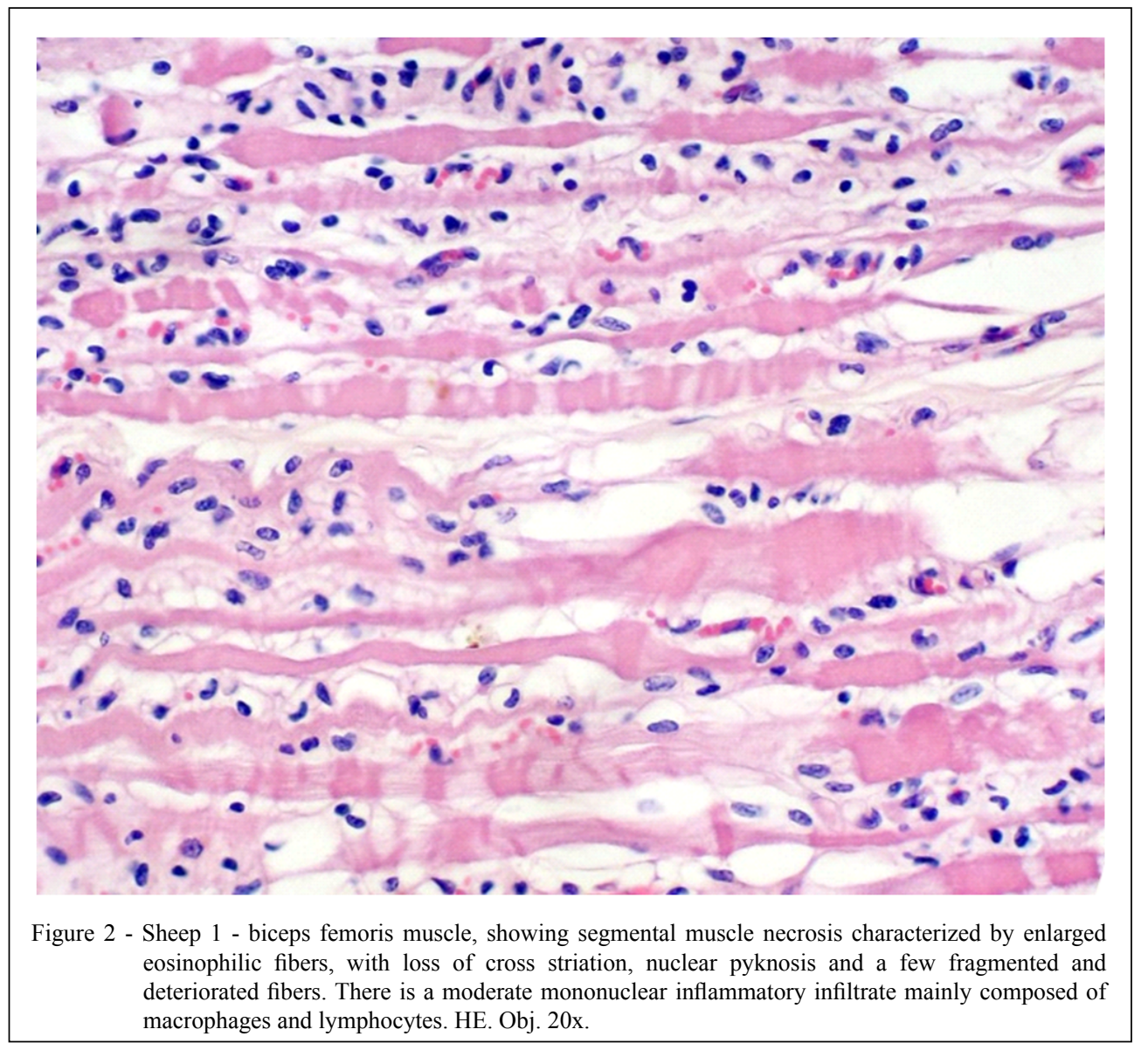

loss of cross striations, and nuclear pyknosis. A few fragmented degenerated fibers showed mineralized areas. Proliferation of satellite cells and mild to moderated mononuclear inflammatory infiltrate mainly composed of macrophages and lymphocytes were also observed.

In sheep 1, the semi membranosus, longissimus lumborum and biceps femoris muscles were more affected. Less severe lesions were seen in the tongue, temporal, diaphragm, psoas major and teres major muscles. Lung was congested, with mild thickening of the alveolar septa and focal to coalescent areas infiltrated by neutrophils, lymphocytes and rare epithelioid macrophages. In sheep 2, areas with moderate muscle fiber segmental necrosis were observed in masseter, semi membranosus, longissimus lumborum and triceps brachii muscles. In the diaphragm muscle the lesions were affecting a fewer number of fibers. In goat 1 the lesions were similar ranging from mild to moderate, located in all muscles collected, but more intense in the masseter, semimembranosus, longissimus lumborum and triceps brachial muscles. In goat 2 the lesions were mainly observed in the semimembranosus, cranial tibial, biceps femoris, superficial gluteal and intercostal muscles. Other organs of all animals did not show significant histological injuries.

\section{DISCUSSION}

Megaesophagus is a rare illness in ruminants whose causes are not well known (RAMADAN, 1993). In a retrospective study of 15 llamas with megaesophagus the etiology was not established for 11 animals. In two animals the illness was associated to degenerative myopathy of the esophagus, one case was attributed to vagal neuropathy and other to toxicity by organophosphorate (WATROUS et al., 1995).

Upon studying the cases in this report it was found that the clinical signs showed by the animals 
resulted from segmental necrosis observed in the esophageal musculature and skeletal muscles. Thus, infection by blue tongue virus, a disease that causes megaesophagus, skeletal musculature necrosis and infiltration by inflammatory cells (ANTONIASSI et al., 2010), was considered among the presumptive diagnoses. Other causes for muscle segmental necrosis are intoxication by ionophore antibiotics and by plants such as Senna occidentalis and Senna obtusifolia (RISSI, 2010; TOKARNIA et al., 2012), in addition to selenium and vitamin E deficiency, already diagnosed in the region (AMORIM et al., 2005). However, the negative results for blue tongue in sheep 1 and goat 2 and the absence of Senna spp. in the pasture exclude both possibilities. There was no history of supplementation with ionophore antibiotics and the epidemiologic aspects and esophageal lesions were not consistent with Se and vitamin E deficiency, since such illness affects mainly rapid growing young animals and there is no record of megaesophagus in the reported clinical picture (AMORIM et al., 2005; RISSI, 2010).

One of the most distinguished aspects in those cases is the fact that, despite the most obvious clinical signs being a result of the megaesophagus, all animals showed segmental muscle necrosis in several muscles. In the description of outbreaks of intoxication by a plant of the genus Geigeria in bovine and sheep in South Africa, in addition to megaesophagus it was also observed degeneration and necrosis in skeletal and esophageal muscles (VANDER, 1993). Thus, it is possible that the cases described are due to the ingestion of a toxic plant not identified yet, since plants of the genus Geigeria are not reported in Brazil.

\section{CONCLUSION}

It was concluded that cases of megaesophagus, with skeletal muscle segmental necrosis, occurs sporadically in goats and sheep in the state of Paraíba and that the disease may be caused by a toxic plant that still unknown as a cause for muscle segmental necrosis.

\section{BIOETHICS AND BIOSSECURITY COMMITTEE APPROVAL}

The paper was approved by the ethics and animal trial committee of the Universidade Federal de Campina Grande (UFCG), process CEP 69-2013.

\section{ACKNOWLEDGMENTS}

The authors acknowledge to Dr. Eduardo Flores from the Universidade Federal de Santa Maria (UFSM) and to Dra E.M.
Pituco from the Instituto Biológico de São Paulo for the research on blue tongue virus. This research was financially supported by the Conselho Nacional de Desenvolvimento Científico e Tecnológico (CNPq) for the Control of Plant Poisonings plants (grant $\mathrm{CNPq}$ 573534/2008-0).

\section{REFERENCES}

ANTONIASSI, N.A.B. et al. Clinical and pathological changes in sheep naturally infected with bluetongue virus in Rio Grande do Sul, Brazil. Pesquisa Veterinária Brasileira, v.30, p.1010-1016, 2010. Available from: <http://www. scielo.br/scielo.php?pid $=$ S0100736X2010001200002\&script =sci_arttt $>$. Accessed: May 13, 2014. doi: 10.1590/S0100736X̄2010001200002.

AMORIM, S.L. et al. Nutritional muscular dystrophy in sheep in Paraíba. Pesquisa Veterinária Brasileira, v.25, p.120124, 2005. Available from: <http://www.scielo.br/scielo. php?script $=$ sci_arttext\&pid=S0100736X2005000200010\&lng= en\&nrm=iso $>$. Accessed: Sept. 04, 2013. doi: 10.1590/S0100736X2005000200010.

BRAUN, U. et al. Regurgitation due to megaesophagus in a ram. Canadian Veterinary Journal, v.31, p.391-392, 1990.

DAME, M.C.F. et al. Doenças hereditárias e defeitos congênitos diagnosticados em Búfalos (Bubalus bubalis) no Brasil. Pesquisa Veterinária Brasileira, v.33, p.831-839, 2013. Available from: $<$ http://www.scielo.br/scielo.php?script=sci arttext\&pid=S01007 36X2013000700001\&lng=en\&nrm=iso>. Accessed: Oct. 5, 2013. doi: $10.1590 / \mathrm{S} 0100-736 \mathrm{X} 2013000700001$

LONGSHORE, R.C. Megaesôfago. In: TILLEY, L.P.; SMITH, F.W.K. Consulta Veterinária em 5 minutos: Canina e felina. 3.ed. São Paulo: Manole, 2008. p.950-951.

MILLER, L.M. et al. Congenital myasthenia gravis in 13 smooth fox terriers. Journal of American Veterinary Medical Association, v.182, p.694-697, 1983.

MOZAFFARI, A.A.; VOSOUGH, D. Idiopathic megaesophagus in a goat: clinical and radiological features. Iranian Journal of Veterinary Sugery, v.2, p.94-96, 2007.

RADOSTITS, O.M. et al. Veterinary Medicine. 10.ed. Elsevier: London, 2007. 2156p.

RAMADAN, R.O. Megaesophagus in a goat. Agri-Practice, v.14, p.26-28, 1993.

RISSI, D.R. et al. Intoxicação espontânea por antibióticos ionóforos em ovinos no Rio Grande do Sul. Pesquisa Veterinária Brasileira, v.30, p.219-221, 2010. Available from: $<$ http://www. scielo.br/scielo.php?script $=$ sci arttext\&pid $=S 0100736 \mathrm{X} 20100003$ 0005\&lng=en\&nrm=iso $>$. Accessed: Sept. 02, 2013, doi: 10.1590/ S0100-736X2010000300005

SHELTON, G.D. Distúrbios musculares e de junção neuromuscular. In: BIRCHARD, S.J.; SHERDING R.G. Manual Saunders de clínica de pequenos animais. 2.ed. São Paulo: Roca, 2003. p.1438.

SPILLMANN, T. Esophageal diseases diagnostic and therapeutic approach. In: ANNUAL WSAVA CONGRESS, 
32., Sydney. Proceedings... Sydney: WSAVA Congress. 2007. Available from: <http://www.vin.com/apputil/ content/defaultadv1.aspx $?$ pId $=11242 \&$ meta $=$ Generic $\&$ cat $I d=31937 \&$ id $=3860784 \&$ ind $=288 \&$ obj TypeID $=17>$. Accessed: Sept. 02, 2013.

TOKARNIA, C.H. et al. Plantas tóxicas do Brasil. 2.ed. Rio de Janeiro: Helianthus, 2012. p.586.

TORRES, P. Megaesophagus in the dog: a bibliographic review and a new classification proposal. Archivos de Medicina Veterinária, v.29, n.1, 1997. Available from: $<$ http://www.scielo.cl/scielo.php?script=sci artt ext\&pid=S $0301732 \times 1997000100002 \& \operatorname{lng}=\mathrm{es} \& \overline{\mathrm{n}} \mathrm{rm}=$ iso>. Accessed: Nov. 17, 2013. doi: 10.4067/S0301$732 \mathrm{X} 1997000100002$.
VANDER LUGT, J.J., VAN HEERDEN, J. Experimental vereersiekte (Geigeria ornativa $\mathrm{O}$. Hoffm. poisoning) in sheep. II: Histological and ultrastructural lesions. Journal of the South African Veterinary Association, v.64, n.2, p.82-88, 1993. Available from: <http://www.ncbi.nlm.nih.gov/pubmed/8410948>. Accessed: Jun.10, 2014

WATROUS, B.J., et al. Megaesophagus in 15 llamas: a retrospective study (1985-1993). Journal of Veterinary Internal Medicine, v.9, p.92-99, 1995. Available from: <http://www.ncbi.nlm.nih.gov/ pubmed/7760315>. Accessed: Jul. 6, 2014. doi: 10.1111/j.19391676.1995.tb03278.x.

VALENTINE, B.A.; McGAVIN, M.D. Skeletal muscle. In: McGAVIN, M.D.; ZACHARY, J.F. Pathologic basis of veterinary disease. 5.ed. St. Louis: Elsevier, 2013. p.871-919. 